\title{
Youth Apathy: A Class Struggle for Student Political Hegemony in Malaysia
}

\author{
KOEY XAN XAN \\ Faculty of Social Science and Humanities, Universiti Malaysia Sarawak, 94300 Kota Samarahan, Sarawak, \\ Malaysia \\ Corresponding author: koeyxanxan@gmail.com
}

\begin{abstract}
On the $10^{\text {th }}$ December 2018, an unprecedented historic event took place in the lower courthouse of the Malaysia Parliament. After years of repressive and regressive stance on student activism, members of parliament voted unanimously to amend the Universities and University Colleges Act 1975, which finally allows student political participation on campus. However, claims of youth apathy and the portrayal of youth in mass media as "unprepared and inexperienced political actors" pose a detrimental dilemma on the participation front. Intrinsic experiences of the youth community, especially from within the confines of universities have been misunderstood, and in fact, very much alienated. Therefore, the impact of the amendment amongst students is assessed in this research. Through exploring the experiences of youth who are caught up between state autonomy and civil liberties, this study employs qualitative research methods through asynchronous in-depth interviews in understanding youth's freedom of expression. The findings are analyzed thematically to extract emergent themes from interviews derived from participants' experiences with bureaucratic structures of the university environment and secondary data on the existing models of polity within the campus. Results show that structural barriers empowered by the existing ideological control provide both perceived positive and negative experiences to the participants. The majority of participants were alienated from the mechanisms of existing democratic institutions and discourses whereas subaltern voices of the youth prevail outside the confines of state-oriented spaces. This study has implications on the Overton Window practices of policymakers in providing true autonomy to students.
\end{abstract}

Keywords: Ideological control, Malaysia, political hegemony, student unions, youth apathy

Copyright: This is an open access article distributed under the terms of the CC-BY-NC-SA (Creative Commons Attribution-NonCommercial-ShareAlike 4.0 International License) which permits unrestricted use, distribution, and reproduction in any medium, for non-commercial purposes, provided the original work of the author(s) is properly cited.

\section{INTRODUCTION}

One ought to remember that participation in student politics is not only about enacting one's university citizenship (Klemenčič \& Bergan, 2015 as cited in Klemenčič \& Park, 2018), but in addition to developing propensities of engaged citizenship within democratic societies. The concept of student politics refers to the activities related to the power relations between students and other social actors in and out of the higher education systems; more explicitly, it pertains to the relationships between the students and the university authorities, as well as the interactions between students and state officials (Klemenčič \& Park, 2018). The systematic juxtaposition of civil societies in reflection of the state is encapsulated in the existence of social movements. In particular, the youth as a working-class mobilizing a class consciousness, which reflects the progress of labor union movements. The increasing prevalence of segregation under the general umbrella of the youth therein lies the fundamental crisis in which, actors caught in the gap between state autonomy and civil liberties often go to war. The term "youth" and "students" are used interchangeably when they are not always related. Portrayed and represented mostly by university students rather than the urban poor or alternative communities by the media and policy makers, youth apathy often connotes to the issues of employment-ability and political succession. The change in dynamics, which accord privileges to students to engage in the political scene, especially as an institutionalized interest group would transform the landscape of society, thus generating a collective consciousness within a class of citizens. A complimentary, interconnected, and interdependent cosmic duality, which keeps the political structure of a nation accountable with its organic checks and balances, certainly enlivens the health of the political system, one's very right to exercise what is known as 
political will. Be that as it may, the reality of such images is not as utopian as it was thought out to be, theoretically. Political cleavages with the intersectionality of social dimensions created new discursive opportunities and therefore restless dissents among the dynamic framework of society.

As Altbach (1989) emphasizes, student movements do not emerge from a vacuum, but are influenced by a social-economical-political environment generally and by governments (and sometimes academic) policies concerning student activism. For 40 years, any form of student activism or dissidents on the Malaysian front line has been curbed using sanctions or legislation from the government through the educational institution, which has severely influenced youth apathy towards politics. Weiss and Aspinall (2012) highlighted that, "as students' political mobilization ramped up, so did the government's efforts to keep activism in check". This was specially stipulated through the Universities and University Colleges Act (UUCA) [Akta Universiti dan Kolej Universiti (AUKU)] 1971 in Malaysia. The counter-response was to create policies that forcibly hinder any participation of student activism within university grounds. As a consequence, the previous government apparatus has kept Malaysian students from achieving political enlightenment that was enshrined back in the sixties, which garnered independence from colonial powers. Throughout the four decades of political suppression using the legislation, student activism was reined in using sanctions and threats. In such instances after the UUCA 1971 was enforced, students were confronted with police brutality and tear gas, which resulted in "more than twelve (12) students injured and one thousand one hundred and twenty-eight $(1,128)$ students arrested" (Karim \& Hamid, 1984). This occurrence led to more protests by students and later gave an excuse for the government to take over the university administration, effective immediately. With the upheaval in campus administration, all student-led organizations were suspended and dissolved while university lecturers who had supported the struggles of the students and peasants were apprehended and terminated without further notice (Karim \& Hamid, 1984). Hence, further mitigating the participation of students in politics, which are often deemed radical and dismissed. Due to the structural barrier that was imposed in the seventies, such as "the corporatization of public universities; the National Council of Higher Education Act 1996, which put in place a single governing body to steer the direction of higher education development", student activism was curbed to a minimum (Ministry of Education, 2015). The drastic decline in youth participation in politics also meant the lack of representation in parliament. Because of this long-term repression, youth representation in the parliament is almost nonexistent and stresses a deep sense of alienation among young generations (Altbach, 1989). Therefore, any decision-making process that pertains to matters regarding the youth lacks the support in numbers and the link in terms of the generational gap.

But on the 10th December 2018, an unprecedented historic event took place in the lower house of the Parliament of Malaysia. After years of the repressive and regressive stance on student political apathy, members of parliament voted unanimously to amend the UUCA 1975 that finally allows student political participation on campus (Abdul Rashid, 2019). This political invigoration was inspired by a series of events after Pakatan Harapan, a coalition of four (4) parties ousted the six (6) decade long of the Barisan Nasional regime. The promulgation produced opportunities for students to mobilize momentum. Universiti Malaya (UM) students revived orientation week convoy, marched in protest and featured controversial activist Fahmi Reza to give a lecture on the history of student activism (Yap, 2019). The envisaged spirit of political freedom also mobilized the first establishment of an official student union (SU) in International Islamic University Malaysia (IIUM), which created rippled effects on the public window of discourse regarding the rise of the student movement in Malaysia (Mustafa, 2019). As SU do not exist independently from labor unions in Malaysia, this unprecedented move of amendment signified strong support in legitimizing the progress of representation, collective power, pride in work and fair treatment in the workplace (Crane, 2014). This constitutes the consolidated presence of students as political actors that can lobby interests on a broader platform and influence the fabric of society enough to leave a lasting social transformation. The change in dynamics, which accord privileges to students to engage in the political scene, especially as an institutionalized interest group would transform the landscape of society, thus generating a collective consciousness within a class of citizens. Nevertheless, are the university grounds ready for such pressure? 
This research does not essentialize nor undermine the necessity of the education system. Rather, it critiques the power dynamics within the industry itself. With the critical analysis founded on ideological control, the analysis, deconstruction and interpretation of student movements through the critical lens of Gramsci's Marxism delineates that the power dynamics of students within the public arena of discourse is highly multifaceted and controlled (Gramsci \& Hoare, 1971). Student political awareness is the key element of this study and where youth apathy is its contrast: Are they conscious enough of their own personal activism? The youth who is riddled with a myriad of political, economic, social and environmental issues are the stakeholders in this study; particularly, the students who are set to inherit these dilemmas as a nation. One of the arguments is that the welfare of the youth is rarely represented as the perspectives of the youths are often marginalized and sidelined due to the glaring issue of unemployment (Dass, 2018). The stress and uncertainties in facing modern challenges aggravate the living conditions of the youth such as precarious working conditions, inadequate income, paid internship, and affordable housing. Social inequality as overly presented under the guise of racism, sexism, heterosexism, classism, or ethnocentrism is the nexus to such precarious living conditions. When it is speared with youthful idealism and optimism, students are able to coalesce and shed light on these issues.

This leads us to the next question of SU. There seems to be a paradoxical paradigm at play. The conferred privileges by the previous student bodies of officials such as Majlis Perwakilan Pelajar (MPP) and student leadership clubs are dubious when the dominant mindset of society at large pertains to the notion of partisanship. Are SU independent and autonomous entities that can be a reliable opposing force of accountability? A subsequent issue is, on which sides do the SU choose to adhere to? The fallacy of 'either/or' binarism depicted in the progovernment or pro-opposition positions will be critiqued. In the past, "students' engagement with pro-government groups or component parties of the ruling coalition attracted less opprobrium" (Weiss \& Aspinall, 2012). Why are they (the government) suddenly empowering the voting power of the youth? Is there a beneficial gain that they can capitalize on? Will they galvanize the SU's political connections for their self-interest? This study zeroes in on the recent amendment of UUCA, which finally allowed students to participate in politics within campus grounds. How students collectively reacted towards the announcement and reconcile a class conscience to be deemed as powerful political actors, influence policies, and social narratives within the fabric of society is further scrutinized. Despite that, the trade-offs of having a powerful mechanism that provides space for the social movement to be co-opted or hijacked by extremist views that could be detrimental to the already unstable status quo. Since the student movement revitalization is still in its infant stage, it is a delicate time frame where the grapple for power comes with the formation of SU constitutions. Whoever holds the highest and dominant position within the hierarchy gets to shape the SU accordingly and that will set a precedence to other SU throughout Malaysia. As such, the notion of students being affiliated with an educational institution already provides grounds for suspicion where the imposing process of guidance that leads to indoctrination is still liable. Furthermore, third party individuals or groups, which are politically incentivized will seek the gullibility of students in order to further one's own selfish interest. The tangible harm of this mechanism allows violent and radical outcomes that may destroy institutions or cause greater inequality due to an oversight of consequences. For these reasons, there needs to be guided questions for this research to anchor its analysis. In the analytical framework, these three sets of interconnected questions guide the analysis.

\section{What causes student or youth apathy in politics?}

Why are the youth apathetic towards politics? On the individual level, is it because of the restrictive laws that force one to conform where one's free political will is taken away or is it just pure debilitating ignorance?

This study is conducted with a focus solely on the youth's participation in the national political scene whereby the discourse of youth apathy is to question the legitimacy of youth's freedom of political dissent. Investigations into the role of emotions, students' sense of inclusion, as well as the emergence of different forms of collective identity and its impact on students' short-term and long-term political behaviour would be a valuable 
addition to the existing scholarship. This study is designed to update existing literature regarding Malaysian student movements that was once generalized to be connoted with ethno-religious cleavages.

2. How far is the extent of student-youth, freedom of expression?

As a civil society, what acts are out there to confine or limit the actions of students who protest? How are SUs developing their mechanism and ideology? How does it promote youth participation that is deemed inclusive? Is there some form of hierarchy or bureaucracy barrier that facilitates inequality or used to control the power of SUs? Who or which group influences the narrative in the SU? Are there nuanced demographic inequalities that exist in societies mirrored in SU?

The investigation into the mechanisms and politics that are being formed in student-civil societies within Malaysia's new context, explores the latest characteristics found in the formulation of SUs that would eventually determine the agenda of the movement itself or whether the amendment of UUCA is tokenistic instead. Through the perception garnered by the youth, the significance of SUs and its impact is studied. This can be seen through their values and norms practiced as its foundation as it acknowledges the importance of equity, accountability, transparency, and inclusiveness within the principles of its constitution.

3. Do students collectively have a class conscience to be deemed as powerful political actors to influence policies and social narratives within the fabric of society?

On the national platform, where is the student movement in Malaysia heading towards?

The third objective analyzes, deconstructs and re-interprets student movements through the lens of Marxism that delineates the power dynamics of students within the public arena of discourse. The specific purpose of this study and the research questions it attempts to answer is the direction of the student movement within Malaysia. With the critical analysis founded on ideological control, the general pervasive pattern of student apathy is identified and questioned.

\section{METHODS}

\section{Participants}

Currently, there are 20 public universities in Malaysia where issues of power or status are discussed within the implementation of the SU on each campus. The justification for public universities instead of private sectors is seen in the foci of the Ministry of Higher Education (MOHE)'s policies in implementing SUs, which IIUM's SU is the piloting project, precedence for all other models of its kind (Mustafa, 2019). The study population, which is of central interest to the subject matter of the study, involves youths who are students in higher tertiary education ranging from age 17 to 30 . The range is further narrowed through the roles, knowledge or behaviour towards different groups and their ability to shed light on different aspects of the research. In this case, 20 organizations of the SU taskforce/MPP are contacted. The voices of institutionalized authorities are the subsets of the central population, which will be included rather distinctly. The difference between SU task force and Majlis Perwakilan Pelajar members is in the nuance of legitimacy. SU taskforce are comprised of students who are external members assembled randomly and voluntarily who either is or isn't a part of the Majlis Perwakilan Pelajar. Whereas Majlis Perwakilan Pelajar are students who participated in student campaigns and elections in order to be voted in as some representatives. On the other hand, there are additional groups or sub-populations such as activists, student body leaders and club members that are included because their views and experiences would bring contrasting or complementary insights to the inquiry. This defines the supplementary parent population.

\section{Procedure}

The research activity covered a six (6) month period, from February 24, 2020, to July 24, 2020. Based on the qualitative nature of the study, the research is employed through a parallel case study framework, which is defined 
in Mohajan's (2018) work on case study especially the parallel studies; the cases are all happening and being studied concurrently. An additional period of three weeks as the framing of the spatial continuum was initiated to allow an appropriate adjustment for data collection as well as the process of triangulating the data collected from the participants. This extensive time frame is also justified due to the nature of this heuristic study, which requires one to fully grasp the nuances in different sets of worldviews propagated by numerous participants from all walks of life. The random snowballing technique of collecting the sample population of 1-2 students per university is reasonably large as the nature of the population is quite heterogeneous. Since the number of criteria is small and its requirement for diversity is obligated, the sample size of 20 participants is perfectly sufficient. This has a significant impact on the number of cases that were covered where triangulation of data occurs through virtual ethnography of respondents social account such as Facebook, Twitter, Instagram, Tumblr, Reddit etc. along with official online channels of universities.

\section{Analysis}

This research implements the method of content analysis and analytic induction of a grand narrative. It involves consolidating, reducing, and interpreting what people have said and what the researcher has seen and read (Abdullah, 2019). In a thematic fashion, general patterns would be derived from the first set of data. This specific approach applied in "critical analysis of a qualitative research" whose "goal is to critique and challenge, to transform and empower" (Abdullah, 2019). The factors in human behaviour in youth apathy is identified and codified. Findings for each specific research question and objectives are categorized and ranked on the basis of its relevance and significance. Content analysis of both written and oral interviews along with secondary data mined based on critical research is carried out through the subcategories of several themes constructed from direct quotations from interviews, documents, observations and official reports. Through triangulation from primary respondents' social media platforms (such as Facebook, Twitter, Instagram, Reddit and Tumblr), these sources were confirmed and validated. Mostly qualitative, this research deems it more appropriate than a quantitative as a more nuanced and empirically grounded rethinking of existing paradigm on youth and politics in developing a perspective that both pays closer attention to the systemic barriers to young people's political agency, as well as explores their potential for affecting real social change without leading to a version of the 'youth as powerless' discourse (Rhenigans \& Hollands, 2013). Therefore, this research spends a significant amount of effort in digging deeper into individual cases rather than a large collective.

\section{RESULTS AND DISCUSSION}

\section{Objective 1 - What causes student/youth apathy?}

The first research question prompted the initial assumptions of youth debilitating ignorance in the case of political action. It is with the intention of this guiding principle to investigate the factors in contributing to its apathy. In spite of that, the results revealed a different conception of which the youth aren't apathetic to political systems, but rather active in levels of participation. The revelation is filtered out in several layers of analysis. One including the method of triangulation as proposed in the methodology segment earlier.

Through the first layer of analysis, several key phrases/elements are found in each of the participant's interview:

\section{Compartmentalizing and essentializing youth}

In the 'Public Opinion Survey: Youth Perception on the Economy, Leadership and Current Issues' from the period of 28 June - 1 July 2019, of the 604 youths in Malaysia conducted by independent research firm Merdeka Centre and WATAN, 70\% said they were not interested in politics, while $75 \%$ found politics confusing (International Republican Institute's Center for Insights in Survey Research, 2019). However, the quantitative data does not explain the intrinsic issues, which pertain to the youth. 
All participants in this research claimed to be active socially online but in the same breath they also claimed their expression of political interests is marginal at best. As this majority pattern of response was premised upon the highly contextualized definition of 'politics', the perception of traditional advocacy is met with high expectations of vigorous protest/riots/petitions. Therefore, in their opinion, their contributions are 'comparatively pale' to the experiences of vocal activists. Furthermore, when the participants are asked whether they would consider themselves to be politically invested/active online with politics/just participating for socials, the question is met with several responses which tend toward a negative affirmation, with a slight exemption.

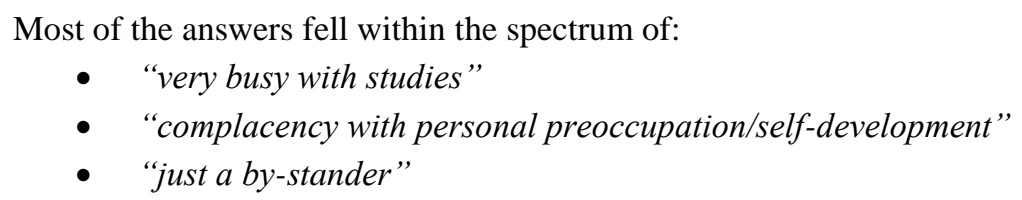

Only a small subset (4 out of 13) would contradict and attest to be somewhat politically active such as one of the participants, find himself to be, in his own words,

"more politically expressive and critical when it comes to nonverbal means of displaying them. Not only that I'm more politically transparent online but also more engaging. Mostly on Twitter because there seems to be a lot of like-minded people there compared to FB and Insta. Most of my political concerns and engagement are supplied by Twitter, although I do go to other platforms such as Reddit and news outlets for further reading and fact checking." (personal communication, June 1, 2020).

What does this mean then? Do students partake in politics without claiming the exclusive actions of activism? Further investigation through data triangulation and clarification later shows that most of their online platforms do contain evidence of participating in politics rather actively. This misalignment of self-identification is due to their definitions of 'politics', which were specifically narrowed either into protest activism, physical advocacy or running for candidacy and joining student body executive councils. While some do attest to wider definitions such as social justice keyboard warriors or online advocacy, yet they do not assume the label/role. This brings up the question in the power dynamics of 'representation'. How identity plays a vital role in assuming roles and responsibilities, but also susceptible to the forces of ideological control by the ruling class. Narrative-wise, the awareness of student-youths in the political environment is arguably an important role in addressing problems to youth apathy. Despite that, its voice of representation is oftentimes distorted or seen as inferior and static. The youth's narrative, which was subsumed and translated within the dominant international framework undergoes countless bureaucratic vetting before it reaches the prestigious platform within the Parliament of Malaysia. This dogmatic exercise exacerbates the structural violence upon the connoted narratives in these communities. Therefore, the angle of which the youth could be perceived as a substantial use in the national discourse of youth apathy should be dissected, analyzed and articulated further. Premised upon the heterogeneity of the youth paradox, arguments for and against the importance of student activism in addressing the problems relating to youth apathy would be discussed thoroughly with regard to the ambiguous concept of 'ageism'.

\section{Power disparity and ageism}

In the '2012 Survey of Malaysian Youth Opinion' poll by the Asia Foundation, 71\% of the youths reported to perceive themselves as less empowered to act, saying they can't make a difference in solving problems within their communities (The Asian Foundation, 2012). In light of this statement, participants were asked whether they engage well or just do the basic minimum requirement and wish to avoid all problems or engagement with their university (academicians, staff or bureaucracy). When asked whether they have a problem with bureaucracy or student politics, what do they think of their peers and how do they deal with issues on university campuses? Most of the participants either believe politics were for 'adults' to regulate or not within their capacity by the rationale with due respect to the 
chain of command. As a result, a combination of both the SOPs and procedure required for students to express their concerns and difficulties can be very discouraging and oftentimes were dealt in a very slow manner. Many would just wait and let someone else to actually voice and highlight the problems, which they would go to the MPP first and subsequently the University administration.

Most of the key phrases were:

- "would not mind doing or following their rules if it is not against my principles"

- "depending on severity of issue and the situation but I trust that there are better people who are managing it"

- "don't want to get myself involved in such a thing and get criticism from everyone"

- "most of us are critics to the system but there's no obvious change being done"

On the other spectrum, two (2) participants, expressed their dilemma in the interview,

- "don't want to be confrontational, not confident"

- "afraid of repercussions and hate conflict"

when asked why they would not relate to the concept of student politics (personal communication, May 11, 2020), therefore opting for opportunistic/utilitarian approach, when needed to further personal interest. This type of nonconfrontational method has led youth-students to resort to numerous ways to adapt in order to survive within a bureaucratic setting and against the backdrop of an authoritative institution.

The general sentiment surrounding these responses according to Gramsci highlight the perpetual dialectical and maieutic relationship established with common sense in order to transform it (and enable it to transform itself) so that a "new common sense" will prevail (Gramsci \& Hoare, 1971; Liguori, 2009). Essentially, dominion over the masses were not just within the acts of political/economic violence and coercion, but also through subtle ideological expressions. The values or norms such as the liberty of decisions only subject to the state being the common sense of all, are part of the bourgeoisie (capitalist-state) developed and indoctrinated hegemonic culture. People in the working-class (the student-youths) identified their own good with the good of the bourgeoisie, and helped to maintain the status quo (through labor/resources whether it be intellectual or physical), rather than revolt. Instead of equalizing the importance of social roles, the seeming portrayal of internalized youth subordination and political powerlessness exhibited by the participants, in actuality, demonstrates the essence of ageism, the supremacy of hierarchy. The structural forms of the political and ideological superstructure such as the intellectual and moral leadership of the University management sector and MPP are indeterminate to Gramsci's theory of "historical bloc" (as cited in Ramos, 1982). This bloc becomes the foundational basis of consent to the hierarchy, and at the same time, it embodies a machine, which produces and perpetuates the hegemony of the ruling class. The network generated through social relations in alliances and compromises both maintain and fracture relations of the economic base. However, this struggle should not be concluded indefinitely from an essentialist framework where social organization of fractured class consciousness is the only mechanism at play. Subsumed by mainstream media or government and ultimate blind respect to the chain of command through political avoidance is actively constructed through various university policies and practices, as well as through the watchful eye of those who hold the power to intervene in youth organizing when it becomes perceived as dangerous and out-of-bounds of proper youth behaviour. Encouraged to avoid politics and define politics narrowly, the result of perpetual struggle of student activism against a system that rewards subordination and inferior complexes are saturated with negative perceptions in mainstream media or the basis of policy makers' range in public window of discourse. But of course, with the recent UUCA amendment, are the youths perceived to have more support or leeway to enact change from the ground up? 


\section{Discrimination within the internal narrative or discourse between students}

In a survey of Malaysian Youth Opinion of their perceived influence on the government, only $41 \%$ of youth today said they could influence how the government works (The Asia Foundation, 2012). Nine (9) out of 13 participants (70\%) stated that they were uninterested in 'playing any student representative role, such as the MPP, Clubs or Councils members', and preferred to 'just be a bystander'. Engagement with university level administrative executives such as staff, bureaucracy and MPPs are met with minimal contact in reasons for doing the basic requirement and wish to avoid all problems or engagement with them. There is a small percentile of participants within the subset who would complain of the abuse of authority in online platforms but are then met with resistance. Whereas the other $30 \%$ of the participants would claim to 'maintain civil and cordial relationships with their university administration in respect to their club/student body organization-related works'. Why is there a large size of participants eluding contact or maintaining a distance from their representative student-bodies? Why are they not receptive towards the engagements coming from MPPs and even some who has so far claimed to surpass the MPP directly in order to deal with their higher authorities to solve an issue. The individualized and asocial theme of the responses are further researched and the clarification showed that there was another angle of measuring the political discussions amongst student-youths, through official channels of "University Confessions" on Facebook where students anonymously post their dissatisfactions online, as highlighted by Ms. Tiffany Pung in one of her interviews (personal communication, May 31, 2020). Empirical data found online are collected from these sources, which add to the collective sentiment of youth dissatisfaction with internal university politics, administrative policies and bureaucracy production. However, the complacency was the compounding tone of most participants. One of the participants who emphasized the priority of self-improvement and was preoccupied with personal agendas rationalized that there were experts who are manning the executive roles even though they were doubtful of it. When questioned further, the participant found that the notion of students partaking in politics detrimental, as pointed out by a USM student (who stressed her wish to remain anonymous),

"from my perspective, student politics cause a lot of distractions to students and it deters their attention from their main goal which is their education. This is because students tend to get caught up in all the political turmoil and be consumed by it i.e. skipping classes to go and participate in their friend's political campaign." (personal communication, May 25, 2020).

This sentiment was largely supported by $90 \%$ of the participants. This inherent normalization of reductive responsibility is seen as a complex interplay between class consciousness of the subaltern and state as delineated by Gramsci (Gramsci \& Hoare, 1971). The common sense characterized "(a) as the prevailing and often implicit 'conception of the world' of a social or regional group; and (b) as something that is the opposite of a developed and coherent worldview" (Liguori, 2009) seems to be vastly intertwined with the agenda of the capitalist-state. Which is to say the cultural hegemonic influence of the ruling class over the working class is deeply infiltrated to the point where some of the youths are readily handing over their autonomy in regards to assume the responsibility of providing an available labor resource to the national agenda. Despite that, this does not answer the reason as to why the youth would rather conform instead of critiquing the 'natural common sense' or revolting against the status quo. Hence, this leads to the subsequent element.

When the participants are asked, 'do they relate to the youth/student movement', or 'they have a problem with bureaucracy or student politics that ties into their relationship to the movement, most of the participants (80\%) in this research responded with keen awareness of the internal student politics going on in their campuses. However, they do not relate nor define themselves collectively to the student movement in Malaysia. Some would even go as far to say that it is absent. 
The key reasoning/phrases collected are:

- "social movements are very based on connections/some are group oriented where if you know someone only you will get a position, one must know the back doors to get in anyway...no credit for talent"

- "students getting serious about politics create more segregated groupings"

- "don't want to get into trouble as their supporters will attack us"

- "student election is filled with unnecessary drama and distractions"

- "prefer to be in clubs/societies that's inclusive of all races rather than one singular race."

- "university is the only place that should be kept clean from any 'politics'.

- " "people who are in politics are because of ego, they do not care about the welfare of students"

While there are quite a number of students who claim that they are political, much of the discourse tends to incline towards partisan arguments between Malaysian political parties and rarely the larger socio-political landscape of the governing system and structure. They are aware of the general discursive debate about 'why this political party is better than the other' or 'why this person is the better politician' but negating the space to instead highlight crucial matters of ideologies, policies and welfare. This type of political discourse is much reflected in the campus where the social organization of students is confined and reduced to only party vs party narrative. They are predominantly partisanship based instead of critiquing the rules of the system itself. Hence, the political climate for student activism is stifled and limited within these variations.

Despite that, when the analysis of responses is compared with the response analysis recorded by other researchers in other seven countries such as the 'Youth Participation in Democratic Life' Survey (2011-2012), it is found that the interpretation of these elements misconstrued the concept of participation (Cammaerts, Bruter, Banaji, Harrison, \& Anstead, 2014). Level of participation does not only consist of voting as political behaviour, but also within one's capability of affecting change through the sharing of information on social media websites (such as Facebook, Twitter \& Instagram), joining the online political discourse (on Reddit/Tumblr) and etcetera.

When assessing young people's attitudes towards democratic life in the UK, France, Spain, Austria, Finland, and Hungary, data suggests that young people are willing to engage politically but are "turned off by the focus and nature of existing mainstream political discourse and practice, which many believe excludes them and ignores their needs and interests. Contrary to the assumptions of the disaffected and apathetic citizen approach, there is a strong desire amongst many young Europeans to participate in democratic life, but this desire is not met by existing democratic institutions" and discourses (Cammaerts, Bruter, Banaji, Harrison, \& Anstead, 2014). This fundamental misconception is reflected within the interview session of this research where student-youths are exhibiting lack of enthusiasm towards the discussion of traditional polity. The case in which the systemic barriers empowered by ideological control exist within the status quo of traditional polity. Ergo, the two final key elements filtered from the data to summarize youth's alienation into traditional politics are:

I. Cultural hegemony

The findings of this research were supported by the existence of evidence in authoritative and bureaucratic regimes within the university grounds, which exercises a political, intellectual, and moral role of leadership. The success of the authoritative regime in shutting down dissent through mechanisms and policies that are being formed in the new student-civil societies are seen in the SUs within Malaysia's new context where they are still heavily monitored and suppressed. Consequences such as active and subtle reproaches dissuade students while slow and discouraging university's standard operating procedures restricts the empowerment of student-youth freedom of expression. 
II. Lack resources for political engagement

The suppression and relatively low amount of alternative outlet of expression are key to confirming the lack of political resources. There are sufficient forums and events to be somewhat politically engaging for students to go and join but it is still very much controlled and mostly are organized by the faculty themselves, not the students.

The youth are not simply apathetic, rather alienated. There is not a simple benign conclusion as to why but the next best question critiques the structures within university grounds. This entreats the question of what mechanisms are in place, which supports this existing ideological control?

\section{Objective 2 - How far is the extent of student-youth freedom of expression?}

Rheingans and Hollands (2013) argued for a more nuanced and empirically grounded rethinking of existing youth and political paradigms in developing a perspective that both pays closer attention to the systemic barriers to the young people's political agency, as well as their potential for affecting real social change without once more leading to a version of the 'youth as powerless' discourse. The governance structure which allows for more youth to be emboldened with a proper political thinking than just simply talking about whose political viewpoints are better.

As a civil society, what acts are out there to confine or limit the actions of students who protest? How are SUs developing their mechanism and ideology? How does it promote youth participation that is deemed inclusive? Is there some form of hierarchy or bureaucracy barrier that facilitates inequality or used to control the power of SUs? Who or which group influences the narrative in the SU? Are there nuanced demographic inequalities that exist in societies mirrored in SUs?

The mechanism proposed by SU lobbyists such as Dr Zaid bin Omar from the Ministry of Higher Education's representative and speaker on lobbying SU constructions across Malaysia is reflected in Figure 1:

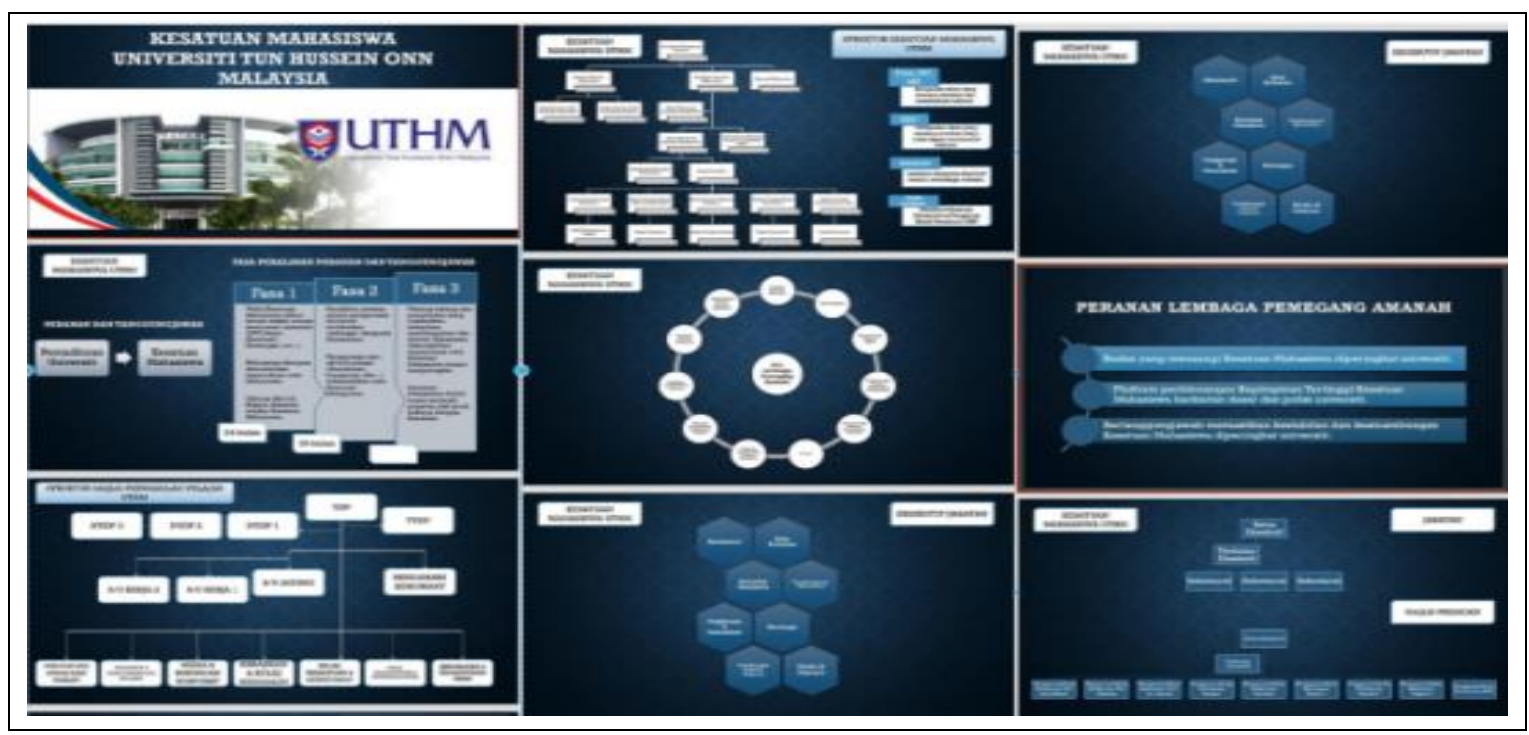

Figure 1. Model and framework recommendations by the Ministry of Education. Source: UTHM Student Union Facebook Page, 2020 
In political theory, meaningful participation is defined as a sharing of power. In the framework of Gramsci's hegemonic culture, predominance by consent is cemented by a condition in which a fundamental class exercises a political, intellectual, and moral role of leadership by a common worldview over another class (Gramsci $\&$ Hoare, 1971). This conception of ideology and revolution was often combined with a reductionist interpretation of ideology, which argued that ideologies necessarily had a class character, so that there was an ideology of the capitalist class and an ideology of the working class, both ideologies antagonistic, defined, and mutually exclusive in their totality. Therefore, exacerbating the emphasis on the role of state institutions' superstructural and infrastructural foundations of class power as a backdrop against contemporary news and government reports.

For 40 years, any form of student activism or dissent on the Malaysian frontline has been curbed using sanctions or legislations from governments through the educational institution, which has severely influenced youth apathy towards politics. On December 2018, the Dewan Rakyat passed amendments to the UUCA, and other related laws, thus allowing university students to participate in political activities (Kow, 2018). The new amendments were gazetted into law effective March 15, 2019. The structures of power relations erected by the state to maintain subordination and control lies within the leadership of the student representative council. In Malaysia's university environment, this is observed through the roles in which student societies play such as MPP, Jawatankuasa Sekretariat Universiti and SUs. The latest characteristics discovered in the proposed formulation of SUs should be acknowledged as that would eventually determine the agenda of the student-youth movement itself. However, the establishment's progress through the perception garnered by the current national political structure is unpredictable. The significance of SUs and its impact has to be studied continuously. This can be seen through their values and norms whether it acknowledges the importance of equity, accountability, transparency, and inclusiveness within the principles of its constitution. In this research, the key elements mined from a comparative analysis between the mechanism proposed by SU lobbyists and the mechanism within the MPP's current administrative system showed contrasting evidence. The contradictions are summarized below:

"The SU is not a body that performs the tasks differently as a whole, they are just rightfully acclaimed with the true autonomy they deserve. The MPP would still hold onto both the administrative or bureaucratic demands of students. The proposed model of SU propagated by KPM absorbs the MPP bodies within the new structure. Take the example of Universiti Malaya and Universiti Kebangsaan Malaysia, although there are other universities who have changed the name of the student body entity. These university student bodies' have changed the name of their MPP to Kesatuan Mahasiswa even though the functions they execute are still the same as before. Part of the response from the administrative side, as quoted from a representative of an MPP in UMT, delineates that there are other universities who have changed the name of the student body entity to rebrand themselves" (personal communication, March 23, 2020).

The unpredictable shift in policy implementation due to the change of government cabinets halted the internal politics of task force members in constituting the SU currently where there are dynamics of power plays between students who are representative of MPP and of those minority voices against the restrictive model. According to the alternative-activist group, the preoccupation with bureaucracy as proposed by the representatives of MPP negates the ability for students to discuss on an inclusive platform.

"Implying on the UUCA; as long as it is around the students will never have the autonomy that is rightfully theirs. The Ministry's ideal version of $S U$ is within the limitations and restrictions of the law however the law implemented must be amended leaning towards students' autonomy and academic freedom. When the participants were asked regarding the UUCA amendment, their response was that the amendment is perceived as tokenistic and through the perception garnered by the youths, the significance of SUs and its impact is marginal" (personal communications, March 20, 2020). 
Nevertheless, the available platforms or structural mechanisms in the status quo, which supposedly allow students to voice their concerns are marginal at best. As supported by another MPP from University Malaysia Perlis said, that the SU task force committee received a low rate of participants and are represented by the same members in his university's MPP, which he himself admitted and as quoted, "To be frank, I don't know why I am even involved with task force" (personal communication, March 4, 2020). Currently, there are some task-force committees whose construction of SUs is manipulated for the convenience of meeting the universities' requirement, which defeats the purpose of establishing SUs in the first place.

For now, until the removal of the Section 15(2)(b) of UUCA, the amendment is tokenistic (Act A1433, Universities and University Colleges (Amendment) Act 2012). Hence, the extent of the student-youth, freedom of expression is limited to university education. The findings exhibited that the shift of power fundamentally does not provide meaningful participation. The youth/students need to rely on alternative platforms outside the regulation of the state to exit limiting existing discourse.

\section{Objective 3 - Do students collectively have a class conscience?}

Ideological control through subtle instruments of oppression can be identified by questioning about who has the power, how is power negotiated, what structures (policy) in society reinforce (increase/strengthen) the current distribution of power and, so on. It is also assumed that people unconsciously accept things the way they are, and in doing so, reinforce the status quo (current state). Others may act in seemingly self-destructive or counterproductive ways of resisting (resistant to change and development) the status quo.

Comparative analysis of the current existing structures within MPPs around Malaysia through observation method and content analysis of their official records posted online suggests an elaboration of the dialectical relationship between the base and the superstructure (Ramos, 1982). Hence, the structural analysis of the roles and its civic practices on university grounds are conducted.

\section{The roles of MPP}

Ideological control of the capitalist state through its infrastructure is seen in the subtle instruments of oppression and social organization of MPP. The elements which portray Gramsci's Praxis of hegemonic influences are through forms of symbolic production, collective practices and rituals (Gramsci as cited in Ramos, 1982). In this case, representative emblems, slogans and specifically tailored uniformed suits in social structures reflects a separation of class as reflected within the MPP's current hierarchal administrative system (Figure 2):

This is further exacerbated with the constant reproduction of posts on Facebook, Twitter and Telegram. The exclusive community where its membership into elite groups enables privileges (i.e. connections), encourages people to accept the supremacy of its hierarchy and to conform to the power relations identified as the leader and the led, reflecting segregation by ethnicity and gender. Most of the members within the MPP are predominantly Malays with a disproportionate ratio of men to women. This reflects the ruling class's prerogative in maintaining an established hierarchy according to ethnicity and gender. The geographical distribution between the East and West Peninsular of Malaysia emphasizes the distinction where the East is ethnically more diverse than the West. Furthermore, concentrations of support in financial, facilities and recognition allocation shown through congratulatory and appreciation posts. This legitimizes their position as consolidated by the university administration, the mass media and government. The MPP becomes a tool for the ruling class (i.e. the capitalist state) to perpetuate propaganda by socially stratifying the students into a classist/ageist society. In addition, most decisions made behind closed doors negate the ability for student-youths of subaltern classes to partake in the decision-making process. This severely affects the youth's agency in aspiring for state power. The youth must strive to attain hegemony in civil society by making its challenge against the dominant class while conforming itself to the interests and aspirations of other subaltern classes (Ramos, 1982). The SUs' developing mechanism and ideology are hijacked by MPP's or other powerful student body representatives who influence the narrative of the SU in the 
making. Hence, this is the success of the authoritative regime in shutting down dissent subtly by manipulating the structural mechanism within the environment.

Therefore, directing its attention into the tradition of civic practices within university grounds, the ruling class can intellectually dominate the other social classes by imposing a worldview that ideologically justifies the social, political, and economic status quo of the society as if it were a natural and normal, inevitable, and perpetual state of affairs that always has been so.

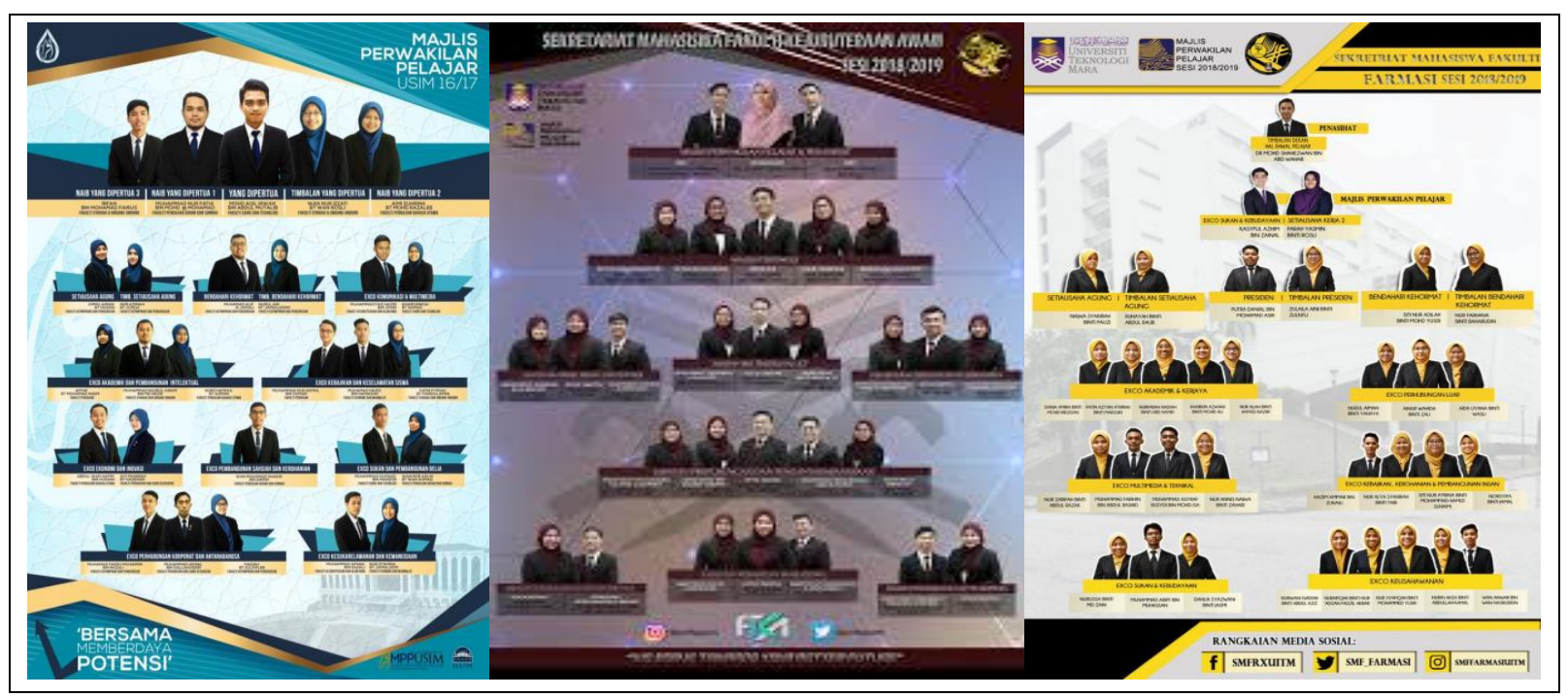

Figure 2. Examples of MPP organization charts. Source: MPP Facebook Pages, 2020

\section{The civic practices within university grounds}

The mechanisms and politics that are being formed in student-civil societies such as SUs within Malaysia's new context are heavily monitored and suppressed. Data from triangulation of accessible channels conducted through virtual ethnography shows that there is only a handful methods to influence policies; either having connections to elected officials of MPP/future SU members, approaching the administrative staff or directly meeting the higher chain of command. Even then, these channels are not easily accessible physically. Due to limited alternative outlet/platform to engage in political discourse or to air grievances, the attention shifts to the online platform. Through several intervals of time, this research has conducted multiple attempts in reaching out to these channels as they represent one of the primary method/tools of contact and interaction from officials and the general student population. However, it is met with slow responses and is a problem-solution mismatch as most of these channels either do not respond at all or delayed communication for weeks.

These consequences disincentivize students while slow and discouraging university's standard operating procedures restricts the empowerment of student-youth freedom of expression. Despite that, there are often misinterpretations of activism, which connotes bi-partisanship and violent protests (personal communications, May $25,2020)$, hence, negating any sort of narrowly defined 'political' involvement in campus. The lack of political platform/outlet due to fear of the UUCA repercussions mitigates the membership of youth/students into politics.

With the critical analysis founded on ideological control, the analysis, deconstruction, and interpretation of student movements through the critical lens of Gramsci's Marxism delineates that the power dynamics of students within the public arena of discourse are highly multifaceted and controlled (Gramsci as cited in Ramos, 1982). The 
specific purpose of this study and the research questions it attempts to answer reveals the layers of the struggles and levels of participation intrinsically fought by the youth. Whether the youth's contribution is debilitating or an exaltation to the movement in general, is not the goal of this research. Rather, it is the interpretation and the adapted evolution of the movement itself in the eyes of the youth. Outside the confines of the state institution, students collectively have a class conscience to be deemed as powerful political actors to influence policies and social narratives within the fabric of society. This is seen through diverse online participations such as forums, debate platforms and social chat rooms on Facebook, Twitter, Instagram, Reddit and Tumblr.

\section{CONCLUSION}

Nevertheless, the research on these communities negates the misconception of apathy, the youths are rather alienated. Student-youths are exhibiting a lack of enthusiasm towards the discussion within the confines of traditional polity; the case in which the systemic barriers empowered by ideological control exist within the status quo of the traditional polity. Not only that, but this study also updates existing literature regarding Malaysian student movements that were once generalized to be connotative of ethnoreligious cleavages with another intersectionality of age-power dynamics (Weiss, 2005). This research does not essentialize nor simply undermine the necessity of the education system, rather it critiques the power dynamics within the industry itself. Klemenčič and Bergan's (2015) stance of the organizational model of student participation would be an important explanatory factor for the policy influence strategy. However, the importance of this element, which was missing, is a (strong) causality between the model and the influence strategy. The missing links which are cultural factors such as the governance style used (interactive or non-interactive) and personal factors (both student representative and the policymaker) influence the strategy employed became the pillars of this in-depth research. The framing of the policy in execution is lost in translation. Therefore, negating the full positive impact of the initial intended outcomes. This research reveals that the social proxies of students are saturated with prerogatives characterized by the capitalistic interest which are state-sanctioned idealism. Citing Sartre's experience of "death consciousness", the reflexive free will in learning is restricted by the inability to question, critique and challenge or stray away from the conventional, narrow, limited path that the system has set upon youths (Howells, 1992). With the critical analysis founded on ideological control, the analysis, deconstruction, and interpretation of student movements through the critical lens of Gramsci's Marxism delineates that the power dynamics of students within the public arena of discourse are highly multifaceted and controlled (Gramsci as cited in Ramos, 1982). The specific purpose of this study and the research questions it attempts to answer in the direction of the student movement within Malaysia and its capability to form a class consciousness reveals the layers of the struggles and levels of participation intrinsically fought by the youth.

\section{Contribution and Recommendation of Study}

This research informs that in any given hegemonic system undergoing an organic crisis, a subaltern but fundamental class aspiring for state power in that system must strive to attain hegemony in civil society by making its challenge against the dominant class while conforming itself to the interests and aspirations of other subaltern classes (Ramos, 1982). The level of consciousness needs to keep up with the current globalized digital capitalistic world that allows the student-youth to shine in their unique and dynamic way. The set of practices, normally governed by overtly or tacitly accepted rules and of a ritual or symbolic nature, which seek to inculcate certain values and norms of behaviour by repetition through traditional means of politics hampers the dissenting voices (Hobsbawm \& Ranger, 1983). Therefore, it is imperative that the student-youth community can still have a voice outside the confines of universities or state-oriented platforms. 


\section{REFERENCES}

Abdul Rashid, H. R. (2019). UUCA amendment passed, allows students' political involvement on-campus. New Straits Times. Retrieved June 16, 2020, from https://www.nst.com.my/news/government-public-policy/2018/ 12/439333/uuca-amendment-passed-allows-students-political.

Abdullah, H. (2019). Research methods and report writing. UPNM Press, National Defense University of Malaysia.

Act A1433, Universities and University Colleges (Amendment) Act 2012, Laws of Malaysia. Retrieved January 12, 2020, from http://www.federalgazette.agc.gov.my/outputaktap/20120622A1433BIAct\%20A1433\%20BIuniversities\% 20and\%20university\%20colleges\%20(amendment).pdf

Altbach, P. G. (1989). Perspectives on student political activism. Comparative Education, 25(1), 97-110.

Cammaerts, B., Bruter, M., Banaji, S., Harrison, S., \& Anstead, N. (2014). The myth of youth apathy: Young Europeans' critical attitudes toward democratic life. American Behavioural Scientist, 58(5), 645-664.

Crane, J. (2014). Labor unions today. Union Plus. Retrieved February 13, 2020 from https://www.unionplus.org/ page/labor-unions-today

Dass, A. (2018, August 6). Young and jobless in Malaysia. The Star. Retrieved February 18, 2020 from https:// www.thestar.com.my/ business/business-news/2018/08/06/young-and-jobless-in-malaysia/

Gramsci, A., \& Hoare, Q. (1971). Selections from the prison notebooks (p. 276). London: Lawrence and Wishart.

Hobsbawm, E. J., \& Terence, O. R. (1983). The invention of tradition. Past and present publications. Cambridge, New York: Cambridge University Press.

Howells, C. (Ed.). (1992). The Cambridge Companion to Sartre. Cambridge University Press.

International Republican Institute's Center for Insights in Survey Research (CISR) (2019). National Survey of Malaysia Youth Public Opinion. July 2-8. Retrieved March 21, 2020, from https://www.iri.org/sites/default/ files/wysiwyg/malaysia_youth_national_survey_july_2019.pdf

Karim, H., \& Hamid, S. N. (1984). With the people: the Malaysian student movement, 1967-74. Institut Analisa Sosial (Malaysia).

Klemenčič, M., \& Bergan, S. (2015). Student engagement in Europe: society, higher education and student governance. Council of Europe Higher Education Series No. 20 (Vol. 20). Council of Europe.

Klemenčič, M., \& Park, B. Y. (2018). Student politics: between representation and activism. Handbook on the Politics of Higher Education, 468.

Kow, G. C. (2018). Dewan Rakyat passes amendment to UUCA. Malaysiakini. Retrieved May 20, 2020, from https://www.malaysiakini.com/news/455607

Liguori, G. (2009). Common sense in Gramsci. In J. Francese (Ed.), Perspectives on Gramsci: Politics, culture and social theory (pp.122-133). Routledge.

Ministry of Education (2015). Malaysia Education Blueprint 2015-2025 (Higher Education). Retrieved March 29, 2020, from https://www.kooperation-international.de/uploads/media/3._Malaysia_Education_Blueprint_ 2015-2025_Higher_Education_.pdf

Mohajan, H. K. (2018). Qualitative research methodology in social sciences and related subjects. Journal of Economic Development, Environment and People, 7(1), 23-48.

Mustafa, Z. (2019). IIUM to be first in establishing a students' union. New Straits Times. Retrieved February 17, 2020 from https://www.nst.com.my/education/2019/06/495693/iium-be-first-establishing-students-union

Ramos Jr, V. (1982). The concepts of ideology, hegemony, and organic intellectuals in Gramsci's Marxism. Theoretical Review, 27(3-8), 34.

Rheingans, R., \& Hollands, R. (2013). 'There is no alternative?': challenging dominant understandings of youth politics in late modernity through a case study of the 2010 UK student occupation movement. Journal of Youth Studies, 16(4), 546-564.

The Asia Foundation. (2012). "The Youth Factor 2012 Survey of Malaysian Youth Opinion”. Retrieved March 10, 2020, from https://asiafoundation.org/resources/pdfs/2012NationalYouthSurvey.pdf

Weiss, M. L. (2005). Still with the people? The chequered path of student activism in Malaysia. South East Asia Research, 13(3), 290-331.

Weiss, M. L., \& Aspinall, E. (Eds.). (2012). Student activism in Asia: Between protest and powerlessness. University of Minnesota Press.

Yap, F. (2019). After 40 years, UM students revive orientation week convoy. Malaysiakini. Retrieved April 25, 2020, from https://www.malaysiakini.com/news/490926 